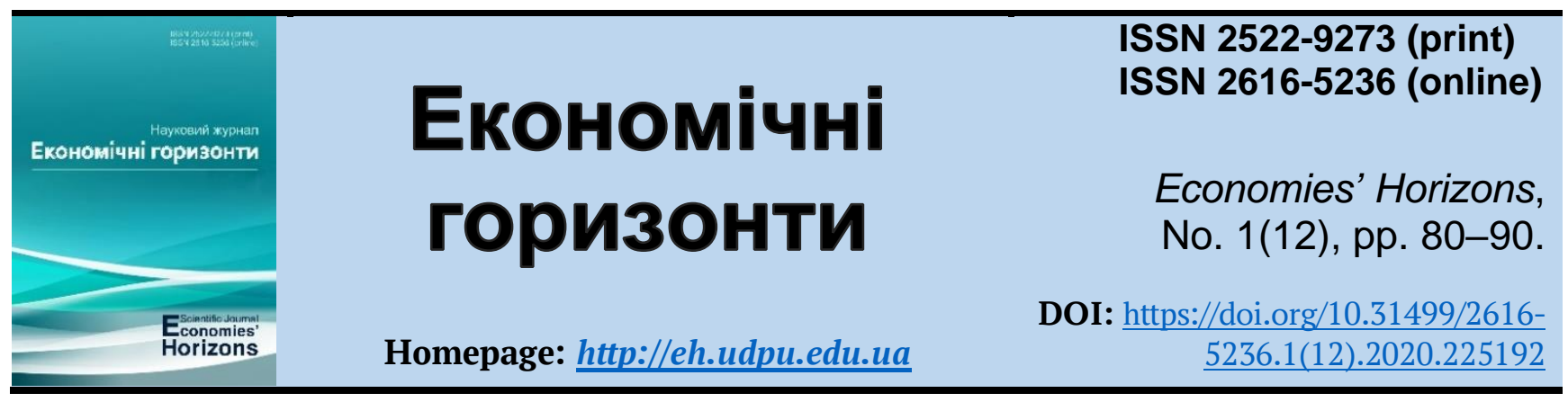

UDC 332.142

\title{
Strategic imperatives of sustainable economic and social development of the region in transformational conditions
}

Received: 17 February 2020 Accepted: 19 March 2020

\begin{abstract}
Dmytro S. Voit ${ }^{1}$, Cand. Ec. Sc.
Voit, D.S. (2020), "Strategic imperatives of sustainable economic and social development of the region in transformational conditions", Economies' Horizons, no. 4(11), pp. 80-90, doi: https://doi.org/10.31499/2616-5236.1(12).2020.225192
\end{abstract}

Abstract. The purpose of the article is to substantiate the strategic imperatives of sustainable economic and social development of the region in transformational conditions. Methodology. The general scientific methods are used in the research, in particular: theoretical generalization - to define the concept of strategic imperatives; methods of positive and normative analysis - to substantiate the strategic imperatives of sustainable economic and social development of the region in transformational conditions. Results. It is proved that the basic strategic imperatives for the development of the region in the strategic perspective are the criteria of sustainability of all formation and implementation processes of regional strategy, namely: ensuring coherence (preferably a synergistic effect) between economic efficiency, social welfare and environmental security. To ensure effectiveness, these imperatives should be specified in certain criteria and norms, which are the main guidelines for goal setting and decision-making at all levels of regional governance.

The model provides for that the imperatives of sustainable strategic development of the regions have a pervasive and comprehensive impact on the processes of formation and implementation of socio-economic development strategies. This is done by aligning the decisions taken with the main criteria to ensure a balance between the economic, social and environmental vectors of their implementation. The imperative criteria of sustainable development of the region are systematized; relevant subsystems and tools for their implementation in transformational conditions are identified.

Practical meaning. The issue of ensuring the development of the real economy should remain a priority of budget policy in modern conditions, as the formation of the budget is carried out precisely through its functioning. At the stage of formation, budget funds should be

\footnotetext{
${ }^{1}$ International University of Business and Law; Candidate of Economic Sciences; doctoral student; ORCID ID: https://orcid.org/0000-0003-3406-2237; e-mail: management@nuos.edu.ua.
} 
Voit D.S. Strategic imperatives of sustainable economic and social development of the region in transformational conditions

primarily directed to investing in infrastructure projects within the region, which will increase the competitiveness of the economy and business activity (economic component), create additional jobs (social component). Prospects for further research. The selection of projects should be carried out taking into account its construction and implementation impact on the ecological state of the territories (ecological component).

Keywords: strategic imperatives, sustainable development of the region, transformational conditions, socialization.

JEL Classification: H11, H55, H77, R11, Q56.

Number of references: 10; number of tables: 0; number of figures: $\mathbf{0}$; number of formulas: $\mathbf{0 .}$

\title{
Стратегічні імперативи сталого економічного та соціального розвитку регіону в трансформаційних умовах
}

\author{
Дмитро Сергійович Войт ${ }^{1}$ к. е. н.
}

Стаття надійшла: 17.02 .2020

Стаття прийнята: 19.03.2020
Voit D. S. Strategic imperatives of sustainable economic and social development of the region in transformational conditions. Економічні горизонти. 2020. № 1(12). C. 80-90. DOI: 10.31499/2616-5236.1(12).2020.225192

Анотація. Метою статmі $\epsilon$ обгрунтування стратегічних імператив сталого економічного та соціального розвитку регіону в трансформаційних умовах. Методологія. У досліджені застосовані загальнонаукові методи, зокрема: теоретичне узагальнення - для визначення поняття стратегічних імператив; методи позитивного і нормативного аналізу - для обгрунтування стратегічних імператив сталого економічного та соціального розвитку регіону в трансформаційних умовах. Результати. Доведено, що базовими стратегічними імперативами розвитку регіону у стратегічній перспективі є критерії сталості всіх процесів формування та реалізації регіональної стратегії, а саме: забезпечення гармонії (в ідеалі синергічного ефекту) між економічною ефективністю, соціальним благополуччям та екологічною безпекою. Для забезпечення дієвості, вказані імперативи повинні конкретизуватися у визначених критеріях та нормах, які є основними настановами для формування цілей та прийняття рішень на всіх рівнях управління регіоном.

Обгрунтовано модель управління стратегічним розвитком регіону у контексті стратегічних імператив. Дана модель передбачає, що імперативи сталого стратегічного розвитку регіонів здійснюють наскрізний та комплексний вплив на процеси формування і реалізації регіональних стратегій шляхом узгодження рішень, що приймаються із основними критеріями для забезпечення балансу між економічним, соціальним й екологічним вектором їх реалізації. Систематизовано імперативні критерії сталого розвитку регіону, визначено відповідальні підсистеми та інструменти їх реалізації в трансформацій-

\footnotetext{
${ }^{1}$ Міжнародний університет бізнесу і права; кандидат економічних наук; докторант; ідентифікатор ORCID: https://orcid.org/0000-0003-3406-2237; e-mail: management@nuos.edu.ua.
} 
них умовах. Практичне значення. Пріоритетним напрямком бюджетної політики в сучасних умовах повинно залишатися питання забезпечення розвитку реальної економіки, оскільки формування бюджету здійснюються саме за рахунок іï функціонування. На етапі становлення, бюджеті кошти повинні першочергово спрямовуватися в інвестування інфраструктурних проектів в межах регіону, що дозволить підвищувати конкурентоспроможність економіки та ділову активність (економічна складова), створити додаткові робочі місця (соціальна складова). Перспективи подальших досліджень. Відбір проектів повинен здійснюватися з урахуванням впливу його будівництва і реалізації на екологічний стан територій (екологічна складова).

Ключові слова: стратегічні імперативи, сталий розвиток регіону, трансформаційні умови, соціалізація.

Кількість джерел: 10; кількість таблиць: 0; кількість рисунків: 0; кількість формул: 0.

\section{Introduction.}

Problems of providing the regions' sustainable development in the long run become urgent in the transformational conditions of our country, characterized by instability of political and economic situation, contradictory processes of formation of the legal field of socioeconomic relations and implementation of the administrative and structural reforms.

An important tool for the management of regions and individual administrative-territorial entities is the strategy choice and effective mechanisms for its implementation. Today, almost all the regions, municipalities and individual integrated communities have developed strategies for socio-economic development. The strategies are developed on the results of a comprehensive SWOT-analysis which considers opportunities, threats, identifies strengths, competitive advantages and weaknesses of the region, outlines the goals of strategic development for the future and possible options for their imple- mentation. The tools for strategy implementation are plans and programs that are aimed at achieving certain social or economic goals and are funded mainly from local or central budgets.

\section{Literature review.}

Ukrainian and foreign scientists have paid considerable attention to the study of the strategic imperatives of sustainable economic and social development of the region in transformational conditions, in particular I. Kramarenko, O. Senkevich and D. Voit, (2020), M. Ilina and Y. Shpylova (2017) V. Marhitych (2019), Z. Herasymchyk and I. Svyda (2018), M. Bondarets (2013), M. Lyvdar (2016) I. Irtyshcheva, T. Stroyko and I. Krupitsa, (2015) and others. However, first of all, the lack of a comprehensive conceptual vision of the model of the region's functioning in the strategic perspective, which will ensure a balance of interests between government, business, and the public, requires additional research. 
Voit D. S. Strategic imperatives of sustainable economic and social development of the region in transformational conditions

\section{Methodology.}

The scientific works of scientists in managing the social development of the region are the theoretical and methodological basis of the study. To achieve the purpose of the study, the following research methods were used: theoretical generalization - to define the concept of strategic imperatives; methods of positive and normative analysis - to substantiate the strategic imperatives of sustainable economic and social development of the region in transformational conditions.

\section{Research objectives.}

The purpose of the article is to substantiate the strategic imperatives of sustainable economic and social development of the region in transformational conditions.

\section{Results and discussions.}

The research has shown that the level of implementation of strategic goals and programs in certain areas is unbalanced and selective. And most of the targets are not achieved due to the lack of a systematic approach and effective mechanisms for regulating social and economic processes, conflicts over the strategic vision of the certain sectors and territories development, lengthy administrative procedures for decision-making and allocation of funds.

In our opinion, the main problem of strategic development management today is first of all the lack of a comprehensive conceptual vision of the model of the region's functioning in the strategic perspective. Such a vision of the model would provide a balance of interests between government, business, and the public, and unite the efforts of all actors in the regional system to achieve common and mutually beneficial goals focused on sustainable economic growth, well-being, and the best use of resources. Such goals, in our opinion, should be the imperatives of the region's strategic development, which will play the role of a cross-cutting regulator of socio-economic processes and decisionmaking at all levels.

Implementation of strategic imperatives at all levels will help to provide transparency of administration, logic and priority of decisions, clarification of strategic development vectors of territories and communities. This, in turn, will increase the level of predictability and stability of the regional environment as an important prerequisite for intensifying investment processes and reducing social tensions.

The term "imperative" is of Latin origin from the word "imperativus", which means "authoritative". Most scientists understand imperatives as principles that are formally or informally binding, unquestioningly adhered to by all participants in the system, which has a positive effect on the efficiency and sustainability of its operation.

On the opinion of M. Ilina and Y. Shpylova, "Economic imperatives are obligatory, objectively determined principles of conduct of economic systems actors, directions, forms and methods of management, mechanisms, tools and 
means of their implementation. They are binding and are used within the current legal field. That is, an economic imperative - is certain rules of conduct of all structural elements of the economic system, taking into account various factors that affect them" (Ilina and Shpylova, 2017).

In V. Marhitych's work, the imperatives of socio-economic development of a region are understood as certain stable elements that ensure the development of the system in any situation, as well as provide for possible scenarios of the system's response to external changes. (Marhitych, 2019). The author considers such elements to be a set of principles of formation and development of the region's organizational and economic potential, namely: isomorphism, holism, emergence and harmony.

According to Z. Herasymchyk and I. Svyda "strategic management imperatives reflect the desired end result and affect the process of building its achievement" (Herasymchyk and Svyda, 2018). The authors emphasize the inevitability of the path of sustainable development, the goals and objectives of which are the main strategic imperatives for Ukraine as a whole and its structural (administrative, sectoral, institutional) components.

Based on the research, the strategic imperatives of sustainable economic growth of the region are proposed to be understood as a set of sustainable principles (norms, criteria) that create conceptual guidelines for managing the region and its components at all levels and in all spheres of economy and society in strategic development process.

Strategic imperatives may be similar to strategic development goals, but differ in their sustainability and lack of alternatives. The whole system of strategic management of the region is consistent with the strategic imperatives that determine the main ways and limitations of the system to ensure balance and stability.

We agree with the opinion of the scientists that "under certain circumstances and for a certain period of time, an imperative is able to reach the maximum level of its effectiveness. At the next stage, the imbalance between the existing imperative norm and the changed environment in the process of social development gradually increases. There is a need for a qualitative update of the content of the imperative, taking into account the new requirements, and to provide effective interaction in society. Thus, there is a "spiral" development of imperative norms, which are constantly adapting to social change; the process begins to continuously build up new, improved rules of economic and noneconomic interaction of individuals on the basis of the imperatives that have already completed their cycle. At the same time, the form of a separate imperative can be more complicated at each new turn of the spiral; however, in their totality other transformations are probable: some will lose their relevance, while others will gain it (Ilina and Shpylova, 2017).

Thus, despite relatively long-term 
Voit D. S. Strategic imperatives of sustainable economic and social development of the region in transformational conditions

stability, imperatives must evolve with the system and change to provide the efficiency and competitiveness of the system in a transformational environment. In this context, the selected imperatives must meet current trends in the economy and society, focus on solving the most pressing problems and take into account the requirements of the time.

At the national level, the basic concept of development of the economy and society of Ukraine in the strategic perspective is the Strategy of sustainable development. The Sustainable Development Goals were approved by the Cabinet of Ministers on September 15, 2017. They are adapted to the global goals of sustainable development and determine the main priorities of the strategic vector of the national economy and society development (Ministry of Economic Development and Trade of Ukraine, 2017).

The draft strategy of sustainable development by 2030 defines the strategic vision of our country's sustainable development based on ensuring national interests and fulfilling Ukraine's international obligations. It provides for:

"- overcoming imbalances in the economic, social and environmental spheres;

- transformation of economic activity, transition to the principles of "green economy";

- building a peaceful and secure, socially cohesive society with good governance and inclusive institutions;

- providing partnership between pub- lic authorities, local governments, business, science, education and civil society organizations;

- full employment;

- high level of science, education and health care;

- maintaining the environment in a proper state that will ensure the life quality and well-being of present and future generations;

- decentralization and implementation of regional policy, which provides for a harmonious combination of national and regional interests;

- preservation of national cultural values and traditions" (UNDP, 2017).

The scientist M. Bondarets identifies the main problems that hinder the effective transition of countries and their regions to the model of sustainable development, in particular:

“- lack or underdevelopment of feedback mechanisms for monitoring, studying and adaptation to change. Only a few countries have introduced integrated monitoring, i.e. a system of indicators to measure and analyze the links between the components of sustainable development. This helps to monitor the process, manage it effectively and apply the latest approaches to studying and adaptation;

- weak coordination of strategic sustainable development goals with the national budget process. It is a lack of attention on the part of governments and relevant ministries in setting budget priorities in line with the national sustainable development strategy and strategic management 
objectives;

- insufficient horizontal coordination between the national sustainable development strategy and regional and local. Effective national strategies should facilitate the appropriate actions at regional and local levels;

- inefficient application of the political initiatives system in transit countries. To achieve the goals of sustainable development, governments of developed countries use a variety of tools and mechanisms, including political initiatives: regulatory, program, financial, institutional and economic" (Bondarets, 2013).

Thus, it is obvious that the basic strategic imperatives for the development of the region in the strategic perspective are the criteria of sustainability of all formation and implementation processes of regional strategy, namely: ensuring coherence (preferably a synergistic effect) between economic efficiency, social welfare and environmental security. To ensure effectiveness, these imperatives should be specified in certain criteria and norms, which are the main guidelines for goal setting and decision-making at all levels of regional governance.

Shows the management model of the region's strategic development, taking into account the impact of strategic imperatives.

The imperatives of sustainable strategic development of the regions have a pervasive and comprehensive impact on the processes of formation and implementation of socio-economic development strategies. This is done by aligning the decisions taken with the main criteria to ensure a balance between the economic, social and environmental vectors of their implementation. The implementation of imperatives requires clarification and systematization of certain criteria of sustainable development that will be used to coordinate decisions.

Taking into account the Sustainable Development Goals of Ukraine by 2030, the main criteria of strategic management of the region and territories in terms of the main vectors are systematized.

These criteria are the main guidelines for thinking and decision-making in the formation of management models not only at the state and regional levels, but also at the level of local communities, enterprises and organizations, which together will promote safe, equitable and efficient economic development.

The implementation of the strategy of socio-economic development is carried out on the basis of the distribution of management functions between the individual subsystems with the subsequent integration of their efforts in achieving comprehensive goals, taking into account strategic criteria. The main subsystems of the strategic plans, projects and programs implementation at the regional level include: organizational, financial and informational.

The organizational subsystem forms the regional structure, i.e. the distribution of rights, responsibilities and management powers of the region and territories. At the 
Voit D. S. Strategic imperatives of sustainable economic and social development of the region in transformational conditions

current stage, the processes of reorganization of territorial and community management systems at all levels are underway under the influence of decentralization, transformation of property relations, clarification of the administrativeterritorial structure and the growing role of civil society. The ultimate goal of organizational transformations is to build an optimal system of regional governance that meets the principles of subsidiarity, transparency and efficiency and provides a balanced, long-term management at all levels of the region in the context of strategic imperatives.

The financial subsystem should provide the current functioning of the region and contribute to its strategic development in the use of financial instruments. The main financial instrument used in the regional development management system is the budget. According to M. Lyvdar "the budgetary mechanism of local finances and the budgetary mechanism of socioeconomic development of the region are correlated both in part and in general. In the first case, attention is focused on the implementation of certain administrative actions that have administrative and technical in nature; in the second case - on the ability of the budgetary mechanism to influence the development of social and economic spheres of the region (in particular, through the application of special procedures for the development, adoption and implementation of budget decisions)" (Lyvdar, 2016).

Creating an effective subsystem of information support for the management of strategic development processes using modern digital technologies is one of the priorities of regional policy in modern conditions, which requires a comprehensive and balanced approach that provides for:

- intensification of efforts to increase the level of digital literacy and the formation of "digital culture" of the population, improving the skills of civil servants and officials;

- creating conditions for attracting investment in the development of the digital technology industry and the development of digital infrastructure, in particular on the basis of public-private partnership;

- formation of normative-legal provision and motivational programs for introduction of digital technologies in all spheres of the region's economy.

Thus, each of the subsystems uses appropriate mechanisms for regulating and stimulating socio-economic processes to guide them in the necessary direction in order to achieve the goals of regional development. An important condition for providing effective management of socioeconomic development of the region in the context of strategic imperatives implementation is to ensure effective information and communication links and a high level of coherence between government, business and the public on the formation of a common economic, social and environmental policy and the use of mechanisms and separate tools for regulating strategic processes. 
Therefore, in the process of implementing a regional investment strategy it is necessary to rely on the tools of strategic management, consisting of the following components:

- strategic goal, assessment of current and forecast financial and resource constraints, tools to achieve goals that will ensure the achievement of expected results;

- priority to ensure the strategic objectives of the transition of the region's economy to a sustainable innovative path of development, which provides conditions under which the cycle of reproduction of each unit of investment should be a carrier of innovation, improve production technologies and increase their economic, social, environmental efficiency and social efficiency;

- ensuring the selection of priority investment projects of national and regional importance from the standpoint of their compliance with the level and effective opportunities to promote the transformation processes of socio-economic systems to an innovative environmentally efficient model;

- application of reasonable administrative and legal mechanisms and incentives for organizational and financial support of scientific and technical activities;

- introduction of additional organizational and financial levers to stimulate integration processes in the regions in order to create effective investment and innovation clusters;

- research and implementation of the best foreign experience of investment policy taking into account the national specifics of investment realities, continuation of adaptation of the economic and legal environment of investment activity to the general European standards (Kramarenko, Voit and Kravets, 2019).

Study of the approach, which is used in institutional theory as for the analysis of social-economic system, allows forming the following conclusions:

- changes can be both effective and ineffective. Efficiency is determined by the level of transaction costs in the economy and by the ratio of effective and ineffective institutions;

- even if the institutional balance is inefficient, the system can be stable for three main reasons: firstly, due to the getting by the State of relatively large budget profits, secondly, as a result of interest of powerful economic groups in an existing position, that guarantees big profits, and, thirdly, due to too large, in comparison with the existing level, transaction costs associated with the change in equilibrium;- the ratio of effective and ineffective institutions of the system will determine the trajectory of its development;

- institutional changes are possible under the influence of shifts in relative prices or changes of ideology (Irtyshcheva, Stroyko and Krupitsa, 2015).

\section{Conclusions.}

It is proved that the basic strategic imperatives for the development of the region in the strategic perspective are the criteria of sustainability of all formation 
and implementation processes of regional strategy, namely: ensuring coherence (preferably a synergistic effect) between economic efficiency, social welfare and environmental security. To ensure effectiveness, these imperatives should be specified in certain criteria and norms, which are the main guidelines for goal setting and decision-making at all levels of regional governance.

The model provides for that the imperatives of sustainable strategic development of the regions have a pervasive and comprehensive impact on the processes of formation and implementation of socio-economic development strategies. This is done by aligning the decisions taken with the main criteria to ensure a balance between the economic, social and environmental vectors of their implementation. The imperative criteria of sustainable de- velopment of the region are systematized; relevant subsystems and tools for their implementation in transformational conditions are identified.

The issue of ensuring the development of the real economy should remain a priority of budget policy in modern conditions, as the formation of the budget is carried out precisely through its functioning. At the stage of formation, budget funds should be primarily directed to investing in infrastructure projects within the region, which will increase the competitiveness of the economy and business activity (economic component), create additional jobs (social component). In this case, the selection of projects should be carried out taking into account its construction and implementation impact on the ecological state of the territories (ecological component).

\section{References}

Bondarets, M. V. (2013), “Imperatives of globalization of sustainable development of transit countries in crisis", Development Strategy of Ukraine, no. 2, available at: http://jrnl.nau.edu.ua/index.php/SR/article/view/6255 (Accessed 20 January 2020)

Herasymchuk, Z. V. and Svyda, I. V. (2018), "Strategic imperatives for managing sustainable development of the region”, Scientific Bulletin of Kherson State University, no. 31, pp. 156-160.

Ilyina, M. V. and Shpylyova, Y. B. (2017), “Theoretical foundations of the formation of imperatives of economic development of society", Economy and society, no. 9, pp. 221-226.

Irtyshcheva, I. O., Stroyko, T. V. and Krupitsa, I. V. (2015), "Conceptual approaches to the forming of the system of institutional changes management”, Economy and society, no. 1, pp. 74-77.

Kramarenko, I. S., Senkevich, O. F. and Voit, D. S. (2020), "Strategic dominants of formation and development of investment potential: regional and national features”, Black Sea Economic Studies, no. 50/1, pp. 167-175 doi: https://doi.org/10.32843/bses.50-29

Kramarenko, I. S., Voit, D. S. and Kravets, L. O. (2019), "Efficiency of using the investment potential of the national economy in the context of the impact on economic growth", Bulletin of KhNAU, no. 1, pp. 403-413, doi: https://doi.org/10.31359/2312-3427-2019-1-403

Lyvdar, M. V. (2016), "Influence of budget policy on socio-economic development of the region", Economy and society, no. 2, pp. 563-566. 
Marhitych, V. V. (2019), "Imperatives of modeling the organizational and economic potential of the region”, Scientific Bulletin of Uzhgorod University, pp. 71-76, doi: https://doi.org/10.24144/2409-6857.2019.1(53).71-76

Ministry of Economic Development and Trade of Ukraine (2017), "Sustainable development goals: Ukraine”, available at: http://www.un.org.ua/images/SDGs NationalReportUA Web 1.pdf (Accessed 20 January 2020)

UNDP (2017), "Strategy of sustainable development of Ukraine until 2030", available at: https://www.undp.org/content/dam/ukraine/docs/SDGreports/UNDP Strategy v06optimized.pdf (Accessed 20 January 2020).

Цей твір ліцензовано на умовах Ліцензії Creative Commons «/з Зазначенням Авторства - Некомерційна 4.0 Міжнародна» (CC BY-NC 4.0). This is an open access journal and all published articles are licensed under a Creative Commons "Attribution-NonCommercial 4.0 International" (CC BY-NC 4.0). 